\title{
Correction to: The spatial concentration and stability of crime in a South African township
}

\author{
G. D. Breetzke ${ }^{1}\left(\mathbb{0} \cdot\right.$ I. S. Edelstein ${ }^{2,3}(\mathbb{C}$
}

Published online: 15 October 2018

(C) Springer Nature Limited 2018

\section{Correction to: Secur J https://doi.org/10.1057/s41284-018-0145-2}

Unfortunately the co-author of this article was omitted. The authorship should read: G. D. Breetzke - I. S. Edelstein. The authors apologise for this mistake.

The original article can be found online at https://doi.org/10.1057/s41284-018-0145-2.

G. D. Breetzke

greg.breetzke@up.ac.za

1 Department of Geography, Geoinformatics and Meteorology, University of Pretoria, Pretoria 0002, South Africa

2 Human Sciences Research Council, 134 Pretorius Street, Pretoria 0002, South Africa

3 Safety and Violence Initiative, University of Capetown, Private Bag X3, Rondebosch 7701, South Africa 